\title{
Study on the Distribution of Heavy Metals in Flesh and Head of Fishes from Njuwa Lake, Yola Adamawa State Nigeria
}

\author{
U.U. Modibbo , H.M. Maina, S.A. Osemeahon and M.H. Shagal \\ Department of Chemistry, Modibbo Adama University of Technology Yola, P.M.B 2076 Yola, Nigeria
}

\begin{abstract}
This study is aimed to determine the levels of $\mathrm{Pb}, \mathrm{Cd}, \mathrm{Fe}, \mathrm{Zn}$ and $\mathrm{Mn}$ in four fish species from Lake Njuwa Yola Adamawa State using energy dispersive x-ray fluorescence (EDXRF) spectrophotometer. The concentration of heavy metals in both the flesh and head of the four fish species have higher values than the maximum permissible limits in fish by World Health Organization and Federal Environmental Protection Agent. The order of heavy metals concentration in the flesh of the four fish species were as follows: Tilapia zilli Fe > $\mathrm{Zn}>\mathrm{Mn}>\mathrm{Cd}$; Synodontis ocellifer $\mathrm{Fe}>\mathrm{Zn}>\mathrm{Mn}>\mathrm{Cd}$; Clarias geriepinus $\mathrm{Fe}>\mathrm{Zn}>\mathrm{Mn}>\mathrm{Cd}$ and Alestes baremose $\mathrm{Fe}>\mathrm{Zn}>\mathrm{Cd}>\mathrm{M}$. Similarly concentrations of heavy metals in the head of four fish species was observed in the order of Tilapia Zilli $\mathrm{Fe}>\mathrm{Zn}>\mathrm{Mn}>\mathrm{Cd}$; Synodontis ocellifer $\mathrm{Fe}>\mathrm{Zn}>\mathrm{Cd}>\mathrm{Mn}$; Claries geriepinus $\mathrm{Fe}>\mathrm{Zn}>\mathrm{Mn}>\mathrm{Cd}$ and Alestes baremose $\mathrm{Fe}>\mathrm{Zn}>\mathrm{Cd}>\mathrm{Mn}>\mathrm{Pb}$.

Key words: Fish, Flesh, head, heavy Metals, lake Njuwa, Synodontis ocellifer
\end{abstract}

\section{Introduction}

Heavy metals are one major component among various effluents which has attained alarming status as water pollutants over the last few decades due to heavy industrialization [1]. Toxic metals are added in aquatic system from industrial processes, domestic sewage, discharge, steel dust, land runoff and fossil fuel burning. Traces of heavy metals such as $\mathrm{Hg}, \mathrm{Cd}, \mathrm{Pb}, \mathrm{As}, \mathrm{Co}, \mathrm{Mn}, \mathrm{Fe}$ and $\mathrm{Cr}$ have been identified as deleterious to aquatic ecosystem and human health [2]. Excess inputs are man made coming from industrial and mining effluents $(\mathrm{Cd}$, $\mathrm{Cu}, \mathrm{Fe}, \mathrm{Hg}, \mathrm{Pb}$, and $\mathrm{Zn}$ ) pesticides $(\mathrm{Cu}, \mathrm{Hg}$, and $\mathrm{Zu}$ ), the burning of fuels and car exhausts (As, $\mathrm{Ni}, \mathrm{Pb}, \mathrm{V}$ and Zn) [3].

Since the river has become the natural dustbins for discharging all sorts of waste, industrial and other wastes, as well as other factors have been responsible for destroying the natural harmony between biotic and abiotic components of the aquatic ecosystem. This envisages a great concern with the ecology of polluted waters and its perspective with regard to its fitness for biotic community including fisheries [4]. Water being a natural food source for about half of the population of the world needs serious implications as the polluted food could draw not only nutritional complications in terms of diseases or other physiological disorders in human and fish production, but also produce more hazards to the living world on account of a variety of indirect interacting activities in aquatic ecosystem. [5].

The role of heavy metal ions in living systems follows the patterns of natural availability. Certainly there is no life that can survive without the participation of metal ions. Some of the major ions such as $\mathrm{Na}, \mathrm{K}$, $\mathrm{Mg}, \mathrm{Ca}$, are essentials to sustain life. In the same way some of the metals are considered essentials both for plants and animals nutrition, and they serve some useful biological functions in the body. Thus, $\mathrm{Cu}, \mathrm{Co}, \mathrm{Mn}$, Mo, Se and Zn are essential to both plants and animal [6].

However, some metals such as $\mathrm{Cd}, \mathrm{Hg}, \mathrm{Pb}$ and metalloids like $\mathrm{As}, \mathrm{Sb}$ and $\mathrm{Se}$ are considered to be toxic [7].

Heavy metals enter into food chain causing hazardous impact on animals including the humans. Chromium accumulation in an animal's body occurs mainly in liver, where as lead and cadmium accumulation do not vary significantly in different tissues [8].

The aim of this study was to determine the heavy metal concentration ( $\mathrm{Pb}, \mathrm{Cd}, \mathrm{Fe}, \mathrm{Zn}$ and $\mathrm{Mn}$ ) in flesh and head of fish species namely (Tilapia zilli, Synodontis ocellifer, Clarias geriepinus and Alestes baremose) from the Nujwa Lake, since these fish is an important component of the human diet in this area

Study Area:

\section{Materials And Methods}

Njuwa Lake is located in Rugange village of Yola South Local Government Area, Adamawa State. It lies between Lattitude $8^{0} \mathrm{~N}$ and $11^{\circ} \mathrm{N}$, and Longitude $11.5^{\circ} \mathrm{E}$ and $13.5^{\circ} \mathrm{E}$. (Fig.1 and 2) 


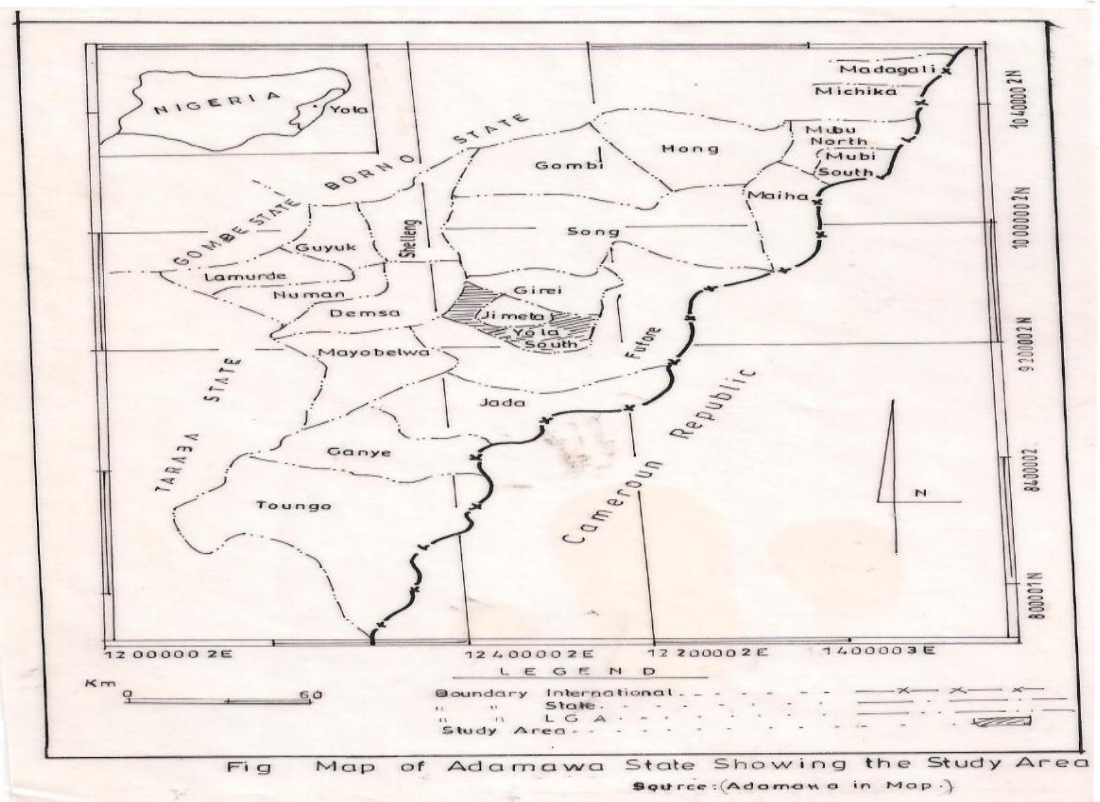

Figure 1 Map of Adamawa State Showing the Study Area

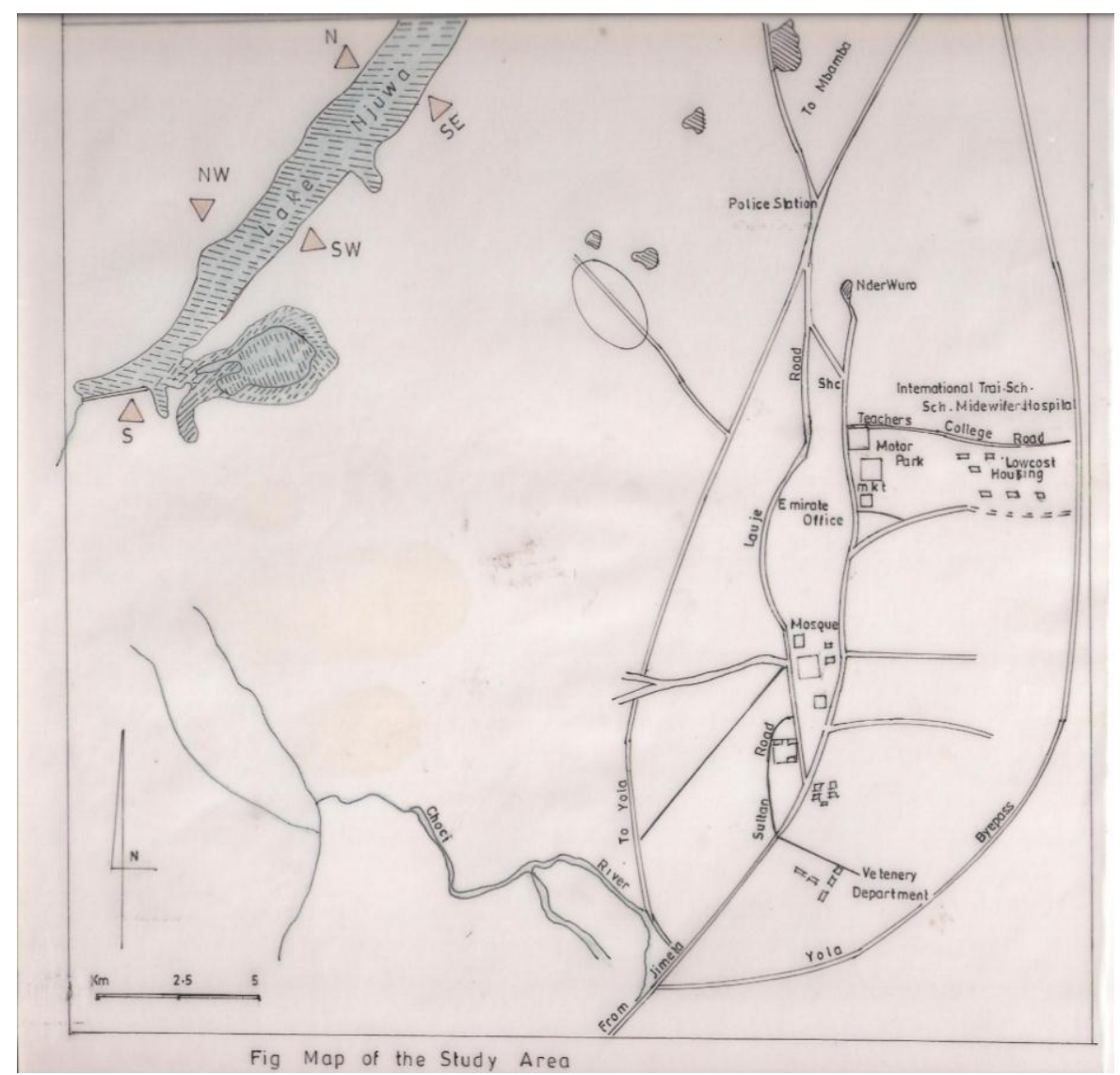

Figure 2 Map of Lake Njuwa Showing Sampling Location.

It experiences some influx of waters during rainy season and pollution load coming up stream from river Benue. The lake has been subjected to intense irrigation, which might have attributed to the major factor for high levels of heavy metals in the lake and fish species. The huge discharges of wastes and heavy metals through this lake system is largely influenced and generated from industrial processes, domestic sewage, land runoff and fossil fuel burning.

Temperature ranges from $20^{\circ} \mathrm{C}$, a cold and dusty winds in December to January and intense heat with temperatures of $30^{\circ} \mathrm{C}$ to $42^{\circ} \mathrm{C}$ in March to April [9] 


\section{Sampling}

Four fish species: Tilapia zilli, Synodontis ocellifer, Clarias geriepinus and Alestes baremose were selected for this study. The selected fishes were the most abundant and commercially important species consumed by the people. Samples were randomly caught by the local fisher men using set gill nets of various sizes and traps set overnight prior to collection. The fish samples were immediately brought at the bank of the Lake. Fish samples were labeled, they were preserved using ice and transported to main laboratory. All the samples were kept at freezing temperature until further pretreatment and analysis.

\section{Fish sample treatment}

The modified version of transmission-emission (T-E) method [10, 11] was used. The fish samples were dissected with clean stainless steel instruments on the same day. The tissues from 5 - 10 individual of the same fish species were dried in an oven at $105^{\circ} \mathrm{C}$ until a constant weight was reached. The dried tissues of the same fish species were ground to powder, sieved to grain size of less than $125 \mu \mathrm{m}$ and were homogenized.

A quantity of $(0.5 \mathrm{~g})$ of the powdered fish sample for each fish species was weighed separately and three drops of organic binder was added to each fish sample and were pressed with 10 tons hydraulic press to form pellets of $19 \mathrm{~mm}$ diameters of each fish sample; three replicate of each fish sample was prepared.

\section{Determination of Heavy Metals in fish Samples.}

The modified version of transmission-emission (T-E) [10, 11] was used. The pellet of each fish sample was put into the X-ray fluorescence spectrophotometer sample holder and it was bombarded with high energy electrons of ${ }^{109} \mathrm{CD}(22.1 \mathrm{Kev})$.

Fluorescent X-ray was produced which passes to silicon-lithium detector, through Mo target as a source of monochromatic X-rays. The spectrum of energy generated on the detector was processed by a multi-channel Analyzer (MCA) to obtain analytical data.

The intensity of fluorescent X-rays on the detector is proportional to the concentration of individual element of interest in the sample.

\section{Results And Discussions}

Concentrations of Lead $(\mathrm{Pb})$, Cadmium $(\mathrm{Cd})$, Iron $(\mathrm{Fe})$, Zinc $(\mathrm{Zn})$, and Manganese $(\mathrm{Mn})$ in fish samples were presented in Table 1 and Table 2

The results of flesh samples in table 1 indicated that, the concentration of the metals were varied from ND $0.23 \pm 0.013 \mu \mathrm{g} / \mathrm{g}$ for Lead, from $0.87 \pm 0.09-1.24 \pm 0.013 \mu \mathrm{g} / \mathrm{g}$ for Cadmium, from $6.33 \pm 0.03-8.28 \pm 0.05$ $\mathrm{mg} / 100 \mathrm{~g}$ for iron, from $3.82 \pm 0.013-4.73 \pm 0.013 \mathrm{mg} / 100 \mathrm{~g}$ for Zinc and $0.95 \pm 0.02-1.25 \pm 0.016 \mathrm{mg} / 100 \mathrm{~g}$ for manganese respectively.

Results of the analysis of head samples in table 2 depicts fish samples namely; Tilapia zilli, Synodontis ocellifer, Clarias geriepinus and Alestes baremose. The heavy metal concentrations were varied from $2.4 \pm$ $0.02-3.91 \pm 0.4 \mu \mathrm{g} / \mathrm{g}$ for Lead, from $1.74 \pm 0.03-2.52 \pm 0.17 \mu \mathrm{g} / \mathrm{g}$ for Cadmium, from $9.63 \pm 0.03-11.71 \pm$ $0.02 \mathrm{mg} / 100 \mathrm{~g}$ for iron, from $6.64 \pm 0.04-8.20 \pm 0.09 \mathrm{mg} / 100 \mathrm{~g}$ for Zinc and from $2.21 \pm 0.09-2.50 \pm 0.06$ $\mathrm{mg} / 100 \mathrm{~g}$ for manganese.

The values obtained for all heavy metals are above national and international standards $[12,13]$

Bioaccumulation of metals in the fish tissues were generally found to be species specific and may be related to their feeding habits and its bio concentration capacity (chemical absorption through skin and gills in the aquatic organism) [2]. Fish absorbed heavy metals from sediments and surrounding waters resulting to their accumulation in reasonable amounts and this observation is reported by several authors in their study of heavy metal concentration $[14,15,16,17]$

The heavy metal concentrations of fish from Njuwa Lake were compared with values recommended by $[12,13]$.

The result of table 1 indicates that $\mathrm{Pb}$ was not detected in the flesh sample of the three fish species namely; Tilapia zilli, Synodontis ocellifer and Clarias geriepinus. The absence of the aforementioned heavy metals in flesh samples of the mentioned species in this study can be attributed to their minute quantities not detected by energy dispersive x-ray fluorescence (EDXRF) spectrophotometer. However Lead was detected in flesh sample of Alestes Baramose in lower quantity of $0.23 \pm 0.013$ and below maximum allowable values for (WHO, 2010) and (FEPA, 2003) with values of $0.050 \mu \mathrm{g} / \mathrm{g}$ and $2 \mu \mathrm{g} / \mathrm{g}$ respectively

Lead is toxic even at low concentration and has no known function in biochemical process. Lead in the environment, is known to be toxic to plants, animals and microorganisms. Lead contamination in the environment exits as an insoluble form, and generally, toxic metals pose serious human health problems namely; brain damage and retardation $[18,19]$. In addition $\mathrm{Cd}, \mathrm{Fe}, \mathrm{Zn}$ and $\mathrm{Mn}$ Were detected in all the fish samples, Iron 
(Fe) was found to be higher than zinc ( $\mathrm{Zn})$, Manganese (Mn), Cadmium (Cd) and Lead (Pb) in all the Samples. The Lead concentration was lower in all the samples.

The level of accumulation $\mathrm{Cd}, \mathrm{Fe}, \mathrm{Zn}$ and $\mathrm{Mn}$ in fish especially in flesh samples were well above the permissible limits as prescribed $[12,13]$ except $(\mathrm{Pb})$ and $(\mathrm{Zn})$ samples which were well below the permissible limit set by [12].

Table 2: Presents the mean concentration of heavy metals determined in samples of head of different fish species from Lake Njuwa. These metal levels were as well compared with [12, 13].

The concentrations of metals were bio accumulated to varying levels.

In the Fish sample of Tillapia zilli, Fe was the most accumulated Iron $(\mathrm{Fe})$ was the most accumulated followed by zinc $(\mathrm{Zn})$ then Lead $(\mathrm{Pb})$ and then manganese $(\mathrm{Mn})$ while Cadmium $(\mathrm{Cd})$ in the table was least accumulated. The value of iron was found higher Synodontis ocellifer than Zinc $(\mathrm{Zn})$ then followed by lead $(\mathrm{Pb})$ and then Manganese while Cadmium (Cd) was the least accumulated in the sample group. Next in the Clarias geriepinus fish sample Iron ( $\mathrm{Fe}$ ) was still found the most accumulated followed by Zinc $(\mathrm{Zn})$ which was found higher than Lead $(\mathrm{Pb})$ and then Manganese $(\mathrm{Mn})$ while Cadmium $(\mathrm{Cd})$ was the least accumulated in the group. Lastly in the Alestes baremose sample Iron ( $\mathrm{Fe}$ ) was found higher than Zinc $(\mathrm{Zn})$, Lead $(\mathrm{Pb})$, Cadmium (Cd), and Manganese (Mn) was the least. In general values of Iron $(\mathrm{Fe})$ were found higher in all the samples in the table. However the concentrations were lower for Cadmium (Cd) and Manganese (Mn) in the group sample.

The results shows that the mean level of heavy metals concentrations in the four fish head samples are much higher than the levels of heavy metals found in the flesh samples reference table 1, thus indicating bioaccumulation in the head of the fish species.

Table 1: Mean Concentrations of Heavy metals in the flesh of four species of fish from Lake Njuwa.

$\mathrm{Pb}$ and $\mathrm{Cd}$ concentrations in $(\mu \mathrm{g} / \mathrm{g})$ and $\mathrm{Fe}, \mathrm{Zn}$, and Mn concentrations in $(\mathrm{mg} / 100 \mathrm{~g}$

\begin{tabular}{|c|c|c|c|c|c|c|}
\hline Metal & & $\mathrm{Pb}$ & $\mathrm{Cd}$ & $\mathrm{Fe}$ & $\mathrm{Zn}$ & $\mathrm{Mn}$ \\
\hline \multirow[t]{5}{*}{ TIllapia zilli Flesh } & & ND & 1.05 & 7.38 & 3.84 & 1.27 \\
\hline & & ND & 1.02 & 7.31 & 3.82 & 1.25 \\
\hline & & ND & 0.97 & 7.03 & 3.81 & 1.23 \\
\hline & Mean + SD & & $1.01 \pm 0.03$ & $7.24 \pm 0.15$ & $3.82 \pm 0.013$ & $1.25 \pm 0.016$ \\
\hline & cV & & 2.79 & 2.07 & 0.34 & 1.28 \\
\hline \multirow[t]{5}{*}{ Synodontis ocellifer Flesh } & & ND & 1.22 & 8.32 & 4.33 & 1.08 \\
\hline & & ND & 1.21 & 8.31 & 4.30 & 1.07 \\
\hline & & ND & 1.09 & 8.22 & 4.29 & 1.07 \\
\hline & Mean + SD & & $1.17 \pm 0.06$ & $8.28 \pm 0.05$ & $4.31 \pm 0.02$ & $1.07 \pm 0.006$ \\
\hline & cV & & 5.13 & 0.60 & 0.46 & 0.56 \\
\hline \multirow[t]{5}{*}{ Clarias geriepinus Flesh } & & ND & 0.98 & 6.37 & 4.11 & 1.17 \\
\hline & & ND & 0.86 & 6.34 & 4.09 & 1.15 \\
\hline & & ND & 0.77 & 6.29 & 4.05 & 1.13 \\
\hline & Mean + SD & & $0.87 \pm 0.09$ & $6.33 \pm 0.03$ & $4.08 \pm 0.03$ & $1.15 \pm 0.02$ \\
\hline & cV & & 10.34 & 0.47 & 0.74 & 1.74 \\
\hline \multirow[t]{5}{*}{ Alestes baremose Flesh } & & 0.24 & 1.28 & 7.38 & 4.74 & 0.97 \\
\hline & & 0.23 & 1.23 & 7.36 & 4.73 & 0.95 \\
\hline & & 0.21 & 1.21 & 7.32 & 4.71 & 0.93 \\
\hline & Mean + SD & $0.23 \pm 0.013$ & $1.24 \pm 0.03$ & $7.35 \pm 0.03$ & $4.73 \pm 0.013$ & $0.95 \pm 0.02$ \\
\hline & CV & 5.65 & 2.42 & 0.408 & 0.27 & 2.16 \\
\hline WHO (2010) & & 0.050 & 0.030 & 0.300 & 1.00 & 0.15 \\
\hline EEPA (2003) & & 2.00 & 0.15 & - & 75.0 & 0.15 \\
\hline
\end{tabular}




$$
\mathrm{ND}=\text { Not Detected } \quad \mathrm{SD}=\text { Standard Deviation } \quad \mathrm{CV}=\text { Coefficient of Variation }
$$

Table 2: Mean Concentrations of Heavy metals in the head of four species of fish from Lake Njuwa.

$\mathrm{Pb}$ and $\mathrm{Cd}$ concentrations in $(\mu \mathrm{g} / \mathrm{g})$ and $\mathrm{Fe}, \mathrm{Zn}$, and $\mathrm{Mn}$ concentrations in $(\mathrm{mg} / \mathbf{1 0 0 g})$

\begin{tabular}{|c|c|c|c|c|c|c|}
\hline \multicolumn{7}{|l|}{ Metal } \\
\hline Fish campte & & $\mathrm{Pb}$ & $\mathrm{Cd}$ & $\mathrm{Fe}$ & $\mathrm{Zn}$ & $\mathrm{Mn}$ \\
\hline \multirow[t]{5}{*}{ Tillapia zilli Head } & & 2.7 & 2.31 & 10.51 & 6.69 & 2.36 \\
\hline & & 2.4 & 2.23 & 10.48 & 6.63 & 2.33 \\
\hline & & 2.1 & 2.20 & 10.39 & 6.60 & 2.30 \\
\hline & Mean + SD & $2.4 \pm 0.02$ & $2.25 \pm 0.05$ & $10.46 \pm 0.06$ & $6.64 \pm 0.04$ & $2.33 \pm 0.02$ \\
\hline & CV & 0.833 & 0.022 & 0.57 & 0.60 & 0.86 \\
\hline \multirow[t]{5}{*}{ Synodontis ocellifer Head } & & 3.47 & 2.41 & 11.73 & 8.21 & 2.58 \\
\hline & & 3.14 & 2.41 & 11.71 & 8.20 & 2.49 \\
\hline & & 3.48 & 2.32 & 11.69 & 8.19 & 2.43 \\
\hline & Mean + SD & $3.36 \pm 0.2$ & $2.38 \pm 0.05$ & $11.71 \pm 0.02$ & $8.20 \pm 0.09$ & $2.50 \pm 0.06$ \\
\hline & CV & 5.95 & 2.10 & 0.17 & 1.09 & 2.40 \\
\hline \multirow[t]{5}{*}{ Clarias geriepinus Head } & & 2.68 & 1.78 & 9.67 & 7.49 & 2.39 \\
\hline & & 2.56 & 1.73 & 9.61 & 7.39 & 2.29 \\
\hline & & 2.44 & 1.71 & 9.60 & 7.37 & 2.22 \\
\hline & Mean + SD & $2.56 \pm 0.11$ & $1.74 \pm 0.03$ & $9.63 \pm 0.03$ & $7.42 \pm 0.03$ & $2.30 \pm 0.07$ \\
\hline & CV & 4.29 & 1.72 & 0.31 & 0.40 & 3.04 \\
\hline \multirow[t]{5}{*}{ Alestes baremose Head } & & 4.22 & 2.72 & 10.85 & 7.66 & 2.22 \\
\hline & & 4.21 & 2.72 & 10.83 & 7.63 & 2.21 \\
\hline & & 3.30 & 2.31 & 10.77 & 7.60 & 2.20 \\
\hline & Mean + SD & $3.91 \pm 0.4$ & $2.52 \pm 0.17$ & $10.82 \pm 0.04$ & $7.63 \pm 0.04$ & $2.21 \pm 0.09$ \\
\hline & CV & 10.23 & 6.75 & 0.37 & 0.52 & 4.07 \\
\hline WHO (2010) & & 0.050 & 0.030 & 0.300 & 1.00 & 0.15 \\
\hline FEPA (2003) & & 2.00 & 0.15 & - & 75.0 & 0.15 \\
\hline
\end{tabular}

\section{Conclusion}

The levels of $\mathrm{Pb}, \mathrm{Cd}, \mathrm{Fe}, \mathrm{Zn}, \mathrm{Mn}$, were higher than the maximum permissible limits in fish set by [12, 13] in fishes.

The results indicate that heavy metals contamination would affect the fishes, and user consumer. Hence a scientific method of detoxification is essential to improve the health of these fishes in any polluted environmental condition.

The results obtained from this study would provide information for background levels of metals in fish species of the lake, thereby contributing to the effective monitoring of the health of the organism inhabiting the lake ecosystem.

\section{Reference}

[1]. Gupta, R.K Gahlawat, S.K. Yadava, N.K, and Jain , K.L. Fundamentals of Ichthyology. Daya Publishing house Delhi, $2007,71-91$.

[2]. Pradipta, K. and Mohapatra. Textbook of Environmental Biotechnology. I.K. International Publishing House Pvt. Ltd New Delhi, 2007, 316- 358

[3]. Ashraj, W. Accumulation of heavy metals in kidney and heart tissues of Epinephelus nicodon fish from the Arabian Gulf. Environmental monitoring Assessment, 1-3 (103) 2005, 311-316. 
[4]. Asaolu, S.S and Olaofe, O. Biomagnifications of some heavy and essential metals in sediment, fishes and crayfish from Ondo state coastal Region, Nigeria, Pak. J. Sci. Ind. Res., 48:2005, 96-102.

[5]. Nwajei, G.E and Gagophien, P.O. Distribution of heavy metals in the sediments of Lagos Lagoon, Pak J. Sci. Ind. Res. 43: 2002, 338-340.

[6]. Atkins, P. Overton, T, Rourke, J., Weiler, M., and Armstrong, F. In Organic Chemistry. Oxford University Press, 2006, 711768 .

[7]. Mathis, B.J. and Keven N.R. Distribution of mercury, cadmium, lead and Thallium in a euthrophic lake. Hydrobiologia., 46 (2-3) $1975, \quad 207-222$

[8]. Oboh, I.P and Edema C.U. Levels of Heavy metals in water and fishes from the River Niger. J. Chem. SOC. Nigeria, 32 (2) 2007, 29-34

[9]. Upper Benue River Basin Development Authority: Annual Report, 1985.

[10]. kump, P. Quantitative analysis of Environmental samples (QAES). Instruction manual, Ljubijana, 1996.

[11]. Angeyo, K.H, Patel, J.P., Managaia, J.M. and Naraya, D.G Optimization of X-ray fluorescence Elemental analysis, an example from Kenyan appl. Radiat. Isot. 49: 1998, 885-891.

[12]. FEPA (Federal Environmental Protection Agency). Guidelines and standards for environmental pollution control in Nigeria, 2003, pp238.

[13]. World Health Organization (WHO). Heavy metals-environment Health criteria. No. 85. Geneva, Switzerland, 2010

[14]. Indrajit, s., Ajay, S and shrivastava, V. Study for determination of heavy metals in fish species of the river Yamuna (Delhi) by inductively coupled plasma-optical emission spectroscopy (ICP-OES). Adv. Appl,SCI. Res.,2(2): 2011,161-166

[15]. Adefemi, S.O; Asaolu, S.S; and Olaofe, O. Determination of Heavy Metals in Tilapia Mossambicuis Fish, Associated water and sediment from Ureje Dam in South-Western Nigeria. Journal of Environmental Sciences, 2 : 2008,151 - 155.

[16]. Akan, J. C; Salwa, M; Yikala, B.S; and Chellube, Z.M. Study on the distribution of Heavy Metals in Different Tissues of Fishes from River Benue in Vinikilang, Admawa State, Nigeria. British Journal of Applied Sciences and Technology 2 (4) 2012 , 311 333 .

[17]. Aderinola, O.J, Clarke, E.O; Olarinmoye, O.M, Kusemiju, V; and M.A Anatekhai. Heavy Metals in Surface water, Sediments, Fish and Perwinkles of Lagos Lagoon. J. Agric and Environment Sci., 5 (5) 2009, $609-617$.

[18]. Bieby, V.T, Siti Rozaimah Sheikh Abdullah; Hussan Basri, Mushrifah Idris; Nurina Anuar; and Muhammad Mukhshin. A Review on Heavy Metals (AS, $\mathrm{Pb}$, and $\mathrm{Hg}$ ) uptake by Plants through Phytoremediation. International Journal of Chemical Engineering Volume 1 (2011), Article ID 939161, P31.

[19]. Jenny, R and Avenant, O.A. Chromium, Copper, iron, and manganese bioaccummulation in some organs and tissues of Oreochromis mussambicus from the lower olifants river, inside the Kringer National Part waqte SA, 23 (4) $2006,387$. 